\title{
Stalking z perspektywy sprawcy i ofiary
}

\author{
AnNa MaLicKa-Ochtera \\ ORCID: 0000-0002-6149-8418 \\ Katedra Prawa \\ Wydział Prawa i Komunikacji Społecznej \\ SWPS Uniwersytetu Humanistycznospołecznego we Wrocławiu \\ członek Izby Adwokackiej we Wrocławiu
}

\section{Czym jest „stalking”?}

Zjawisko stalkingu jest wielowymiarowe. Można na nie patrzeć przez pryzmat nauk humanistycznych zarówno w aspekcie psychologicznym, socjologicznym, społecznym, jak i prawnym. Stalking bliski jest także problematyce medycznej w sferze zaburzeń sprawców, ale i skutków po stronie ofiar oraz społeczeństwa.

Określenie „stalking” pochodzi od angielskiego sformułowania „to stalk”, oznaczającego śledzenie zwierzyny łownej — „to follow a person or animal quietly in order to catch or kill them"1. Słowo „polować" w kontekście stalkingu wywodzi się zatem ze świata zwierząt, z żargonu myśliwskiego, akcentując tym samym specyficzny stosunek łowcy do osaczanej zwierzyny ${ }^{2}$.

W ujęciu prawniczym stalking definiowany jest najczęściej jako uporczywe nękanie, różne formy naruszenia wolności osobistej i prywatności drugiej osoby wywołujące poczucie lęku, zagrożenia i dyskomfort

1 Longman Dictionary of Contemporary English, Essex 1995, s. 139.

2 J. Skarżyńska-Sernaglia, Stalking: od miłości do zbrodni - nowe wyzwania dla psychologii, kryminologii i zespołów interdyscyplinarnych przeciwdziałających przemocy, „Seria Psychologiczna” 2009, nr 1, s. 3-4, http://www.lvduvs.edu.ua/documents_pdf/visnyky/nvsp/01_2009/09ssjipp.pdf(dostęp: 28.03.2020). 
u ofiary. Uciekając od próby definicji równościowej w ujęciu klasycznym, przedstawiciele doktryny często wskazują, że stalkingiem jest natrętne komunikowanie i kontaktowanie się z osobą, która sobie tego nie życzy, podglądanie jej, nachodzenie, śledzenie, wręczanie niemile widzianych podarunków, agresywne zachowanie ${ }^{3}$. W praktyce popularnym narzędziem stosowanym w celu ,stalkowania” jest internet i wszelkie środki oraz metody porozumiewania się na odległość. Dlatego też stalking przybiera obecnie formę ,cyberstalkingu” bądź szerzej — „cyberbullyingu”. Cyberstalking obejmuje takie zjawiska, jak fałszywe oskarżania formułowane w sieci, monitorowanie zachowań osób w sieci, uzyskiwanie dostępu do danych, prezentowanie bez zgody cudzych danych, zdjęć, regularne przesyłanie niechcianych maili. Warto odnotować, że bardzo często ofiara sama przekazuje sprawcy dane, materiały i informacje, choćby aktywnie udzielając się na portalach społecznościowych. Z tego względu sprawcami i ofiarami cyberstalkingu są często luzie młodzi, tak zwane młode i średnie pokolenie, dla którego niejednokrotnie nieudzielanie się na forach internetowych oznacza społeczne wykluczenie ${ }^{4}$.

Zjawisko cyberstalkingu mieści się w szerszej grupie nagannych zachowań określanych jako ,cyberprzestępczość”, pozostając blisko zjawiska tak zwanego cyberbullyingu, czyli celowego, agresywnego i długotrwałego zachowania wobec ofiary z zamiarem sprawienia jej krzywdy ${ }^{5}$.

\section{Znamiona przestępstwa}

Do polskiego ustawodawstwa przestępstwo stalkingu zostało wprowadzone ustawą z 25 lutego 2011 roku o zmianie ustawy — Kodeks karny. Aktualnie, zgodnie z treścią art. 190a, penalizowane jest uporczywe nękanie innej osoby lub osoby jej najbliższej wzbudzające u niej uzasadnione okolicznościami poczucie zagrożenia lub istotnie naruszające jej prywatność. Typ kwalifikowany (§ 3) wskazuje jako następstwo czynu targnięcie

\section{Ibidem, s. 5.}

4 J. Sobczak, K. Kakareko, Nękanie w Internecie, [w:] Stalking, red. M. Mozgawa, Warszawa 2018, s. 197-199, 205-206.

5 Szerzej zob. B. Czuba, M. Dziedziech, Cyberbullying - współczesny wymiar przemocy, „Studia Bezpieczeństwa Narodowego” 2017, z. 12, s. 413-430. 
się na własne życie przez pokrzywdzonego. Stalking jest przestępstwem publicznoskargowym, ściganym na wniosek pokrzywdzonego.

Przechodząc do analizy znamion przestępstwa stalkingu, warto zacząć od podstawowego pytania o dobro chronione prawem, czyli o to, co jest przedmiotem chronionym przez ustawodawcę i jednocześnie przedmiotem zamachu ze strony sprawcy. Zgodnie z tytułem rozdziału XXIII na pierwszy plan bez wątpienia wysuwa się wolność rozumiana w art. 190a k.k. jako prywatność i wolność osobista jednostki. Ustawodawca zatem poprzez art. 190a k.k. chroni szeroko rozumianą wolność jednostki zarówno „od czegoś” (od strachu, nagabywania, niechcianego towarzystwa innej osoby), jak i „do czegoś” — przede wszystkim do poszanowania sfery prywatności ${ }^{6}$.

$\mathrm{Na}$ dalszym, ale tylko pozornie, planie pozostaje dobro w postaci bezpieczeństwa publicznego, rozumiane jako ład społeczny, czyli porządek respektowany dzięki ustaleniu i przestrzeganiu przez jego uczestników norm oraz wartości, w którym jednostka ma prawo żyć w poczuciu dobrostanu psychofizycznego, to jest w stanie wolności od jakichkolwiek form dręczenia, nękania i zastraszania.

W praktyce stosowania prawa najwięcej kontrowersji wywołują znamiona strony przedmiotowej w postaci nękania oraz skutku w formie uzasadnionego okolicznościami poczucia zagrożenia. Próbując odpowiedzieć na pytanie, czym jest nękanie z art. 190a k.k., prowokująco w doktrynie wskazuje się, że ,nie ma nic złego w wysłaniu komuś listu, SMS-a czy złożeniu wizyty. Problem zaczyna się w momencie, gdy np. listów czy SMS-ów pojawia się zdecydowanie za dużo (np. po kilkadziesiąt dziennie), a ich adresat tego sobie nie życzy"7. O uporczywym zachowaniu się sprawcy świadczyć będzie zatem z jednej strony jego szczególne nastawienie psychiczne, wyrażające się w nieustępliwości nękania, to jest trwaniu w swego rodzaju uporze mimo próśb i upomnień od pokrzywdzonego lub innych osób o zaprzestanie przedmiotowych zachowań, z drugiej zaś dłuższy upływ czasu, przez który sprawca je podejmuje. Jednocześnie czynność sprawcza połączona ma być ze skutkiem, którym musi być wytworzenie u pokrzywdzonego uzasadnionego

${ }^{6}$ M. Mozgawa, Analiza ustawowych znamion przestępstwa uporczywego nękania, [w:] Stalking..., s. 39-41.

${ }^{7}$ Kodeks karny. Komentarz aktualizowany, red. M. Mozgawa, Warszawa 2019. 
okolicznościami poczucia zagrożenia lub poczucia istotnego naruszenia jego prywatności ${ }^{8}$.

Aby zachowanie sprawcy mogło być kwalifikowane jako stalking, musi być nękaniem uporczywym, a zatem polegać na nieustannym oraz istotnym naruszaniu prywatności innej osoby oraz na wzbudzeniu w pokrzywdzonym uzasadnionego okolicznościami poczucia zagrożenia. Ustawodawca nie wymaga przy tym, aby w zachowaniu stalkera był element agresji. Co więcej, obojętne dla prawnokarnej reakcji pozostaje, czy czyn sprawcy powodowany jest żywionym do pokrzywdzonego uczuciem miłości, nienawiści, chęcią dokuczenia mu, złośliwością czy chęcią zemsty. Dla bytu tego przestępstwa nie ma więc znaczenia, czy sprawca ma zamiar wykonać swoje przepowiednie bądź groźby. Decydujące jest tu subiektywne odczucie zagrożonego, które musi być obiektywnie uzasadnione ${ }^{9}$. Artykuł 190a $\S 1$ k.k. posługuje się kryterium zarówno subiektywnym w postaci poczucia zagrożenia, oznaczającego wewnętrzny odbiór, odczucie lęku i osaczenia osoby doświadczanej nękaniem, jak i obiektywnym, wskazując, że poczucie zagrożenia musi być uzasadnione okolicznościami. Subiektywne odczuwanie zagrożenia przez osobę należy bowiem konfrontować $\mathrm{z}$ wiedzą, doświadczeniem i psychologią reakcji ogółu społeczeństwa, obiektywizować przez poczucie zagrożenia w danych okolicznościach, jakie towarzyszyłoby przeciętnemu człowiekowi, o ile oczywiście działania sprawcy nie zmaterializowały się w konkretnym skutku.

Działania sprowadzające się do obserwacji, filmowania i fotografowania pokrzywdzonych spoza ich posesji, zamykające się tylko w sferze prywatnego dokumentowania, nieużywane do ściągnięcia na pokrzywdzonych jakiegokolwiek wymiernego zagrożenia, nie wypełniają same z siebie znamienia poczucia zagrożenia $\mathrm{z}$ art. 190a § 1 k.k. Mogą jednak być istotnym naruszeniem prywatności ${ }^{10}$, stanowiąc asumpt do reakcji na gruncie cywilistycznym. W judykaturze przesądzona została kwestia,

${ }^{8}$ Wyrok Sądu Apelacyjnego we Wrocławiu z dnia 19 lutego 2014 roku, sygn. akt II AKa 18/14.

${ }^{9}$ Postanowienie Sądu Najwyższego z dnia 12 grudnia 2013 roku, sygn. akt III KK $417 / 13$.

10 Wyrok Sądu Najwyższego z dnia 29 marca 2017 roku, sygn. akt IV KK 413/16, LEX nr 2281268. 
że aby spełnić znamię odczucie zagrożenia, o którym mowa w treści art. 190a, nie może być jedynie subiektywnie (nawet dotkliwie) odczuwalne, musi zaistnieć jeszcze element obiektywnego uzasadnienia owego odczucia zagrożenia w danych okolicznościach. Przykładowo można wyobrazić sobie sytuację, w której wrażliwa kobieta, zapraszana na kawę, dostając o dwa SMS-y za dużo, może w rozmowie z koleżanką wyrazić poczucie zagrożenia swojej prywatności i wolności, jednakże — o ile działanie sprawcy ogranicza się do dwóch, trzech propozycji i nie ma innych okoliczności świadczących o złej woli działania zapraszającego trudno obiektywnie mówić o poczuciu zagrożenia usprawiedliwionym okolicznościami, którego dotyczy art. 190 a k.k.

\section{Stalker}

Punkt widzenia i ocena rzeczywistości oczami sprawcy przestępstwa stypizowanego w art. 190a k.k., określanego jako stalker, jest odmienna od punktu widzenia pokrzywdzonego. Sprawca narusza ład społeczny i przekracza granice bezpieczeństwa publicznego, będąc powodowany chęcią kontroli i często zaburzeniami psychicznymi, które predestynują go do sprawstwa. Stalker chce uzyskać kontrolę nad sytuacją, panowanie nad pokrzywdzonym, chce dominować, czego skrajnym przejawem jest dopuszczenie się — w ostateczności — przestępstwa zabójstwa. Schematy myślenia sprawców w ich ocenie usprawiedliwiają przekraczanie ogólnie akceptowanych norm społecznych. Stalkerzy najczęściej wykazują niską tolerancję wobec niepowodzeń, błędnie interpretują zachowania innych osób, natarczywie egzekwują własne prawa, są egoistami pozbawionym empatii z problemami uczuciowymi, relacyjnymi i frustracjami ${ }^{11}$.

Ponad 80\% stalkerów to mężczyźni poniżej 40. roku życia ${ }^{12}$. Najczęściej są to osoby psychotyczne, w tym ze schizofrenią, i niepsychotyczne ze stylem osobowości stalkera, to jest z zaburzeniami osobowości typu borderline czy narcystycznymi, psychofani, sprawcy odrzuceni, rozgory-

11 I. Nowicka, Zjawisko stalkingu w kontekście resocjalizacji penitencjarnej. Kilka uwag, „Humanistyczne Zeszyty Naukowe - Prawa Człowieka” 2017, nr 1, s. 165-178.

12 D. Jędrek, Stalking w świetle badań empirycznych, [w:] Stalking..., s. 275. 
czeni, z odwetu, kochający, z potrzebą dominowania. W teorii rozróżnia się sprawców: odrzuconych (rozpoczynają nękanie, gdy partner kończy wspólne życie, i usiłują reaktywować związek), rozgoryczonych (chcą wywołać poczucie lęku), z odwetu (reagują impulsywnie po wyrządzonej im „krzywdzie”), chcących nawiązać więź z ofiarą, nieudolnych zalotników poszukujących relacji (osoby pozbawione ogłady towarzyskiej), drapieżnych (zazwyczaj chcą doprowadzić do działań o charakterze seksualnym $)^{13}$.

Najczęstszymi formami sprawczych działań stalkera są: wydzwanianie, głuche telefony, kręcenie się w okolicy ofiary, nawiązywanie kontaktu z pomocą osoby trzeciej, milczące wystawanie pod oknem, wypytywanie o ofiarę w jej otoczeniu, wysyłanie niechcianych wiadomości, śledzenie, oszczerstwa, nękanie rodziny i przyjaciół ${ }^{14}$. Wśród zachowań stalkera można także wyróżnić: pozostawianie wiadomości, kwiatów czy innych rzeczy niechcianych przez ofiarę, wręczanie niechcianych prezentów, natrętne propozycje spotkań, obserwowanie, podglądanie ofiary, a także jeszcze bardziej ingerencyjne formy, takie jak zakładanie podsłuchu telefonicznego, wdzieranie się do mieszkania, manipulowanie poprzez wszczynanie postępowań sądowych przeciwko ofierze, groźby, akty wandalizmu, szantaż. Przy czym na stopień społecznej szkodliwości wpływa nie tylko stalkera strategia osaczania, lecz także intensywność jego zachowań i okres ich trwania ${ }^{15}$.

Jak zwrócono uwagę w orzecznictwie, stalker działa motywowany różnorodnymi pobudkami, wśród których należy wyróżnić zarówno miłość, nienawiść, jak i złośliwość czy chęć zemsty ${ }^{16}$. Wspólnym mianownikiem wykładni działań sprawcy pozostaje jednak określone nastawienie, wyrażające się w przekorności lub nieustępliwości działań po-

13 J. Bąkowski, Karanie za stalking w świetle praktyki państw obcych, „Palestra” 2013, nr 1-2, s. 292-298; zob. też D. Jędrek, op. cit., s. 273-280.

${ }^{14}$ Zob. szerzej D. Woźniakowska-Fajst, Prawne możliwości walki ze zjawiskiem stalkingu - czy w prawie polskim potrzebna jest penalizacja prześladowania?, „Archiwum Kryminologii” 31, 2009, s. 177.

15 K. Tomaszek, Stalker - psychologiczna charakterystyka sprawców przestęstw „, uporczywego nękania”, ,Studia z Psychologii w Katolickim Uniwersytecie Lubelskim” 18, 2012, red. O. Gorbaniuk et al., s. 140-141.

16 Postanowienie Sądu Najwyższego z dnia 12 grudnia 2013 roku, sygn. akt III KK 417/13, LEX nr 1415121. 
dejmowanych w akcie złej woli ${ }^{17}$. Zatem tło miłości, nienawiści, zemsty czy pogardy musi wypełnić działanie stalkera z natężeniem złych intencji, aby czynność sprawcza mieściła się w znamieniu czasownikowym typu z art. 190a k.k. W praktyce oznacza to liczne trudności dowodowe wymiaru sprawiedliwości, albowiem niejednokrotnie sprawcy tłumaczą się owymi pozytywnymi emocjami, takimi jak miłość czy chęć nawiązania kontaktu, a element złej woli, z racji wysoce wewnętrznego źródła pochodzenia, jest dla organu oceniającego sprawę najtrudniej uchwytny w czynionych ustaleniach dowodowych na podstawie materiału akt sprawy.

\section{Ofiara}

Analizując sytuację i perspektywę ofiary, należy przede wszystkim zauważyć, że w przeważającej większości przypadków występuje więź łącząca sprawcę z ofiarą, przykładowo związek, były związek lub niedoszły związek, a także szersze powiązania, jak relacja lekarz-pacjent, nauczyciel-uczeń, prawnik-klient, współpracownik ${ }^{18}$. Istnienie owej więzi jest najczęściej pierwotną przyczyną wystąpienia emocji, które następnie stają się podłożem uporczywego nękania. Najczęściej w praktyce chodzi o więź intymną łączącą sprawcę z ofiarą ${ }^{19}$. Bywa jednak, że owa więź obiektywnie nie istnieje, jednak sprawca imaginuje sobie ją celem jej rzeczywistego nawiązania.

Ofiarą stalkingu najczęściej są ludzie młodzi, samotni, ale także wykonujący zawody predestynujące do nawiązywania bliższych relacji z drugim człowiekiem, takie jak nauczyciel, lekarz, prawnik. W przeciwieństwie do potencjalnych sprawców większość ofiar stalkingu stanowią młode kobiety, które nie życzą sobie relacji. Grupa wiktymogenna

17 M. Królikowski, A. Sakowicz, [w:] Kodeks karny. Część szczególna. Komentarz, t. 1, red. M. Królikowski, R. Zawłocki, Warszawa 2013, s. 541.

18 D. Jędrek, op. cit., s. 271.

19 P. Tjaden, N. Thoennes, Stalking in America: Findings from the National Violence against Women Survey, National Institute of Justice, NCJ 169592, Washington 1998, s. 6. 
działań sprawcy wskazuje na bezpośredni związek skali przestępczości $\mathrm{z}$ art. 190a k.k. ze środkami komunikowania się na odległość ${ }^{20}$.

\section{Skutki}

Sytuację ofiary przestępstwa stalkignu na pewno można określić jako dyskomfort i poczucie zagrożenia, powodujące różnego rodzaju konsekwencje w świecie zarówno zewnętrznym, jak i wewnętrznym (tak zwane skutki psychofizyczne). W życie ofiary, a także jej bliskich wkrada się niechciany chaos, w teorii zwraca się uwagę nawet na swego rodzaju spustoszenie w psychice ${ }^{21}$. Ofiara stalkera doznaje krzywd natury psychicznej i emocjonalnej, które mogą powodować nawet zaburzenia psychiczne czy też choroby. Życie z poczuciem „oddechu na karku" powoduje bezsenność, nadmierną nerwowość, niepokój, przewlekły stres, bezradność, panikę, depresję, strach, a nawet myśli czy próby samobójcze.

U ofiar stalkingu obserwuje się także zmiany zewnętrzne w funkcjonowaniu w społeczeństwie - stają się one nieufne, mniej przyjazne i cyniczne, zmieniają styl życia i usposobienie. Bardzo często dochodzi do zmian miejsca zamieszkania, numeru telefonu, konta w internecie, miejsca pracy.

Analizując w doktrynie pokrzywdzenie ofiary, wyróżnia się zatem następujące skutki: w postaci ogólnej krzywdy, emocjonalne, poznawcze, psychiczne, społeczne, ekonomiczne, a także, co ciekawe, „pozytywne" - rozwinięcie silniejszych relacji rodzinnych, przyjacielskich, większa ostrożność, zwiększenie samooceny. Ofiara bardzo często podejmuje próby reakcji na stalkowanie przez rozmowę ze sprawcą, ucieczkę, konfrontację, a także szukanie pomocy na zewnątrz (kursy samoobrony, pomoc prawna) $)^{22}$.

Nieodwracalnym i najdalej idącym skutkiem zjawiska stalkingu jest śmierć. Przestępstwo stalkingu zaistniało jako samodzielny typ przestępstwa właśnie ze względu na skutek w postaci zabójstw ofiar stalkingu.

20 D. Jędrek, op. cit., s. 287-288.

21 D. Woźniakowska-Fajst, op. cit., s. 181.

22 D. Jędrek, op. cit., s. 289-295. 
Niejednokrotnie ofiary przestępstw z art. 148 k.k., jak się później okazywało, były uprzednio ofiarami stalkingu, pozostającego do 2011 roku poza sferą zachowań prawnokarnie doniosłych. Przykładowo ofiarami stalkerów były miss Polski Agnieszka Kotlarczyk w 1996 roku czy dentystka Andżelika Krupska w roku 200923. Ostatecznie stalkowana ofiara w obliczu bezradności może podjąć próbę samobójczą, o czym traktuje art. 190a $\S 3$ k.k.

Ciekawym zjawiskiem mieszczącym się w tematyce skutków stalkingu jest także ich „rozproszenie”. W klasycznym modelu przestępstwa skutek czynu dotyczy osoby pokrzywdzonej czy też osób pokrzywdzonych przestępstwem - przykładowo oszustwa, kradzieży, pobicia. W wersji zaprezentowanej w art. 190a k.k. możemy mieć jednakże do czynienia z szerszym polem oddziaływania na bezpieczeństwo publiczne, o czym celnie wspomina J. Kędzierski, podając przykład urzędniczki jednej z instytucji komunalnych, którą nękał petent. Sprawca nachodził ofiarę w miejscu jej pracy, obdarowywał niechcianymi prezentami, czynił propozycje i ją śledził. Urzędniczka bezskutecznie informowała pracodawcę i organy ścigania. Zrozpaczona powiedziała o tym także mężowi, który postanowił położyć kres nękaniu żony. Wieczorem, gdy intruz stał pod domem, małżonek urzędniczki wyszedł pod pretekstem kupienia gazety. Przestraszony intruz, uciekając, oddał strzał ,za siebie”, śmiertelnie raniąc małżonka ${ }^{24}$.

Owo rozproszenie skutków bywa także mniej spektakularne, jednak bardzo odczuwane przez ofiarę i jej bliskich. Stres towarzyszący osobie pokrzywdzonej stalkingiem bardzo często oddziałuje na całą rodzinę czy też środowisko pracy, uniemożliwiając normalne funkcjonowanie. Depresje, załamania nerwowe, zmiana miejsca pobytu to skutki, które mają bezpośrednie przełożenie na życie rodzinne czy też zawodowe ofiary. Skutki stalkingu mają zatem szerszy promień oddziaływania aniżeli tylko na osobę bezpośrednio pokrzywdzoną przestępstwem.

Na marginesie należy zaznaczyć, że przestępstwo stalkingu w prawnej rzeczywistości funkcjonuje jako byt powiązany choćby z instytucją ochrony dóbr osobistych, takich jak życie zdrowie, wolność, cześć, dobre

23 Zob. szerzej D. Woźniakowska-Fajst, op. cit., s. 173-174.

24 J. Kędzierski, Stalking w polskim prawie karnym — de lege lata $i$ de lege ferenda, „Palestra” 2010, nr 1-2, s. 67. 
imię. Jak zwraca uwagę J. Giezek, przed 2011 rokiem to właśnie na płaszczyźnie cywilnej ofiara mogła dochodzić naprawienia szkód i krzywd za uporczywe nękanie w drodze powództwa o naruszenie dóbr osobistych ${ }^{25}$. Bliskie znamionom z art. 190a k.k. pozostaje także przestępstwo znęcania się z art. 207 k.k., które obejmuje ochroną osoby najbliższe lub inne pozostające w stosunku zależności, a także przestępstwo groźby karalnej z art. 190 k.k., które godzi w wolność człowieka od strachu, i przestępstwo zmuszania do określonego zachowania z art. 191 k.k ${ }^{26}$.

\section{Wnioski}

Podsumowując, stwierdzić należy, że perspektywy sprawcy i ofiary stalkingu są wręcz biegunowo od siebie odległe. Symetryczne natomiast pozostaje odczucie naruszenia ładu przez obie strony. Sprawca, powodowany chęcią uzyskania kontroli nad ofiarą, dąży do jej uzyskania i zdominowania pokrzywdzonego, z kolei stalkowana osoba odczuwa silny niepokój, poczucie zagrożenia i niebezpieczeństwa. Zaburzenia natury psychicznej mogą być z jednej strony czynnikiem sprawczym po stronie stalkera, z drugiej zaś skutkiem, którego dozna nękana ofiara, choćby w formie depresji czy też załamania nerwowego.

Mimo ustawowo określonych znamion w art. 190 a k.k. stalking pozostaje zjawiskiem kulturowo zmiennym i elastycznym, wprost proporcjonalnie do stanu określonych i przestrzeganych w społeczeństwie norm, a także do poziomu wrażliwości społeczeństwa. Trudności w precyzyjnym określaniu granic penalizacji stalkingu biorą się dziś właśnie z braku jasno określonych norm społecznych i wartości szanowanych i akceptowanych przez członków społeczeństwa. Podobnie problematyczne staje się wytyczanie granicy cyberstalkingowi przy zjawisku kontratypu zgody dysponenta dobrem prawnym w postaci dobrowolnego udzielania się na portalach społecznościowych, w dobie postępu technologicznego i zmiany w sposobie komunikacji. Poczucie bezpieczeństwa natomiast, które chronić ma także art. 190a k.k., zakłada funkcjonowanie

${ }^{25}$ Kodeks karny. Część szczególna. Komentarz, red. J. Giezek, Warszawa 2014.

26 J. Kosińska, Prawnokarna problematyka stalkingu, „Prokuratura i Prawo” 2008, nr 10, s. 35-38. 
w ładzie społecznym, którego granice są jasno określone i bezwzględnie respektowane.

\section{Bibliografia}

Bąkowski J., Karanie za stalking $w$ świetle praktyki państw obcych, „Palestra 2013, nr 1-2, s. 292-298.

Czuba B., Dziedziech M., Cyberbullying — współczesny wymiar przemocy, „Studia Bezpieczeństwa Narodowego" 2017, z. 12, s. 413-429.

Jędrek D., Stalking w świetle badań empirycznych, [w:] Stalking, red. M. Mozgawa, Warszawa 2018.

Kędzierski J., Stalking w polskim prawie karnym — de lege lata $i$ de lege ferenda, „Palestra" 2010, nr 1-2, s. 67-77.

Kodeks karny. Część szczególna. Komentarz, red. J. Giezek, Warszawa 2014.

Kodeks karny. Komentarz aktualizowany, red. M. Mozgawa, Warszawa 2019.

Kosińska J., Prawnokarna problematyka stalkingu, „Prokuratura i Prawo 2008, nr 10, s. 33-47.

Królikowski M., Sakowicz A., [w:] Kodeks karny. Część szczególna. Komentarz, t. 1, red. M. Królikowski, R. Zawłocki, Warszawa 2013.

Longman Dictionary of Contemporary English, Essex 1995.

Mozgawa M., Analiza ustawowych znamion przestępstwa uporczywego nękania, [w:] Stalking, red. M. Mozgawa, Warszawa 2018.

Mróz K., Stalking, „Palestra” 2019, nr 1-2, s. 194-205.

Nazar K., Glosa do wyroku SN z 12.01.2016 r., IV KK 196/15, „Palestra” 2016, nr 7-8, s. $176-183$.

Nowicka I., Zjawisko stalkingu w kontekście resocjalizacji penitencjarnej. Kilka uwag, „Humanistyczne Zeszyty Naukowe — Prawa Człowieka” 2017, nr 1, s. 165-178.

Skarżyńska-Serngalia J., Stalking: od mitości do zbrodni - nowe wyzwania dla psychologii, kryminologii i zespołów interdyscyplinarnych przeciwdziałajacych przemocy, „Seria Psychologiczna” 2009, nr 1, s. 1-15, http://www.lvduvs.edu.ua/documents_ pdf/visnyky/nvsp/01_2009/09ssjipp.pdf (dostęp: 28.03.2020).

Sobczak J., Kakareko K., Nękanie w Internecie, [w:] Stalking, red. M. Mozgawa, Warszawa 2018.

Tomaszek K., Stalker - psychologiczna charakterystyka sprawców przestępstw uporczywego nękania, „Studia z Psychologii w Katolickim Uniwersytecie Lubelskim” 18, 2012, red. O. Gorbaniuk, B. Kostrubiec-Wojtachnio, D. Musiał, M. Wiechetek, s. $135-156$.

Woźniakowska-Fojst D., Prawne możliwości walki ze zjawiskiem stalkingu - czy w prawie polskim potrzebna jest penalizacja prześladowania?, „Archiwum Kryminologii" 31, 2009, s. 173-208. 


\section{Stalking from the perpetrator's and victim's perspective}

\section{Summary}

Stalking as a crime has been punishable under Polish law since 2011. Etymologically, the term comes from the word "to stalk" — tracking. The criminal perpetrator of the crime violates the social order by violating its rules, motivated by the desire to take control of the victim. The basis of the stalker's causative actions are usually strong emotions such as love, hate or revenge. The victim is a person who most often has or had a personal relationship with the perpetrator, for example a former partner who ended the relationship. The primary effect on the victim's psyche is fear, anxiety, and a sense of danger, followed by mental disorders and even death by murder or suicide. The feeling of social disorder occurs on both the perpetrator's and victim's side. The phenomenon of stalking is plastic, because depends on the boundaries set by norms and values recognized in society.

Keywords: Stalking, cyberstalking, criminal perpetrator, victim, security. 